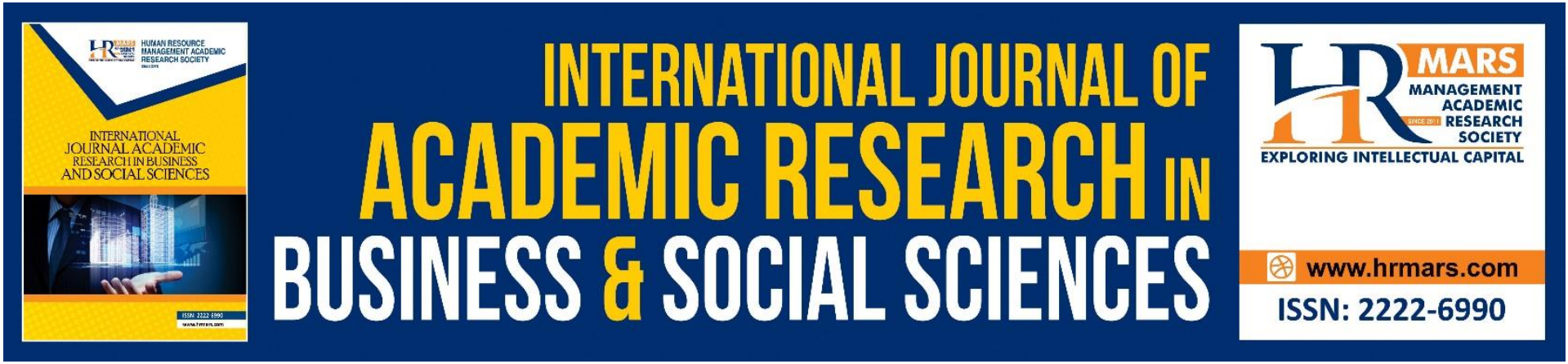

\title{
Community Participation and Human Capital Drawn from Yayasan Sejahtera Project in Malaysia
}

\section{Sara Shakilla Mohd Salim \& Asnarulkhadi Abu Samah}

To Link this Article: http://dx.doi.org/10.6007/IJARBSS/v11-i12/11790～DOI:10.6007/IJARBSS/v11-i12/11790

Received: 21 October 2021, Revised: 24 November 2021, Accepted: 09 December 2021

Published Online: 26 December 2021

In-Text Citation: (Salim \& Samah, 2021)

To Cite this Article: Salim, S. S. M., \& Samah, A. A. (2021). Community Participation and Human Capital Drawn from Yayasan Sejahtera Project in Malaysia. International Journal of Academic Research in Business and Social Sciences, 11(12), 440-449.

Copyright: @ 2021 The Author(s)

Published by Human Resource Management Academic Research Society (www.hrmars.com)

This article is published under the Creative Commons Attribution (CC BY 4.0) license. Anyone may reproduce, distribute, translate and create derivative works of this article (for both commercial and non0-commercial purposes), subject to full attribution to the original publication and authors. The full terms of this license may be seen at: http://creativecommons.org/licences/by/4.0/legalcode

Vol. 11, No. 12, 2021, Pg. $440-449$

Full Terms \& Conditions of access and use can be found at http://hrmars.com/index.php/pages/detail/publication-ethics 


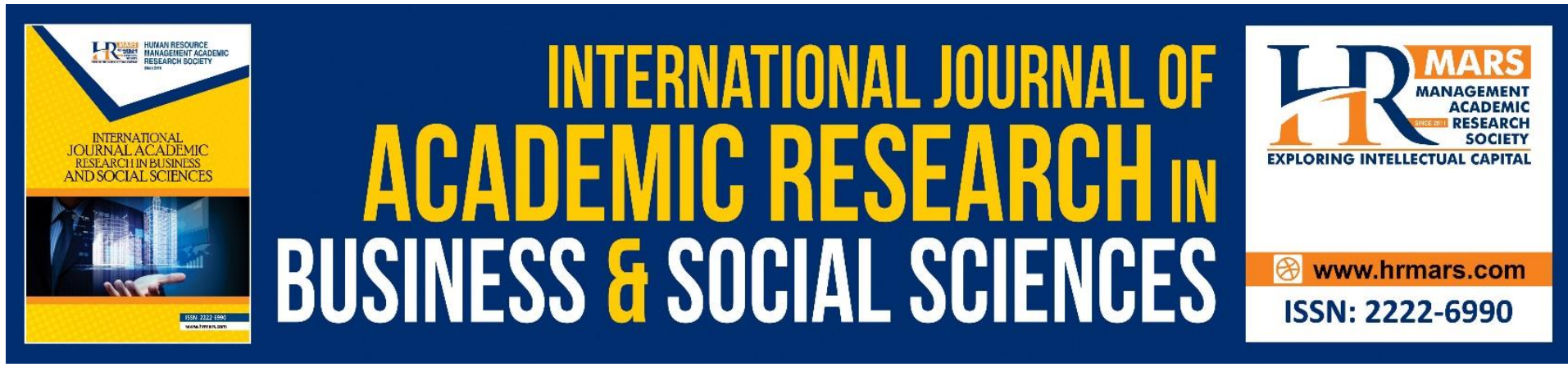

\title{
Community Participation and Human Capital Drawn from Yayasan Sejahtera Project in Malaysia
}

\author{
Sara Shakilla Mohd Salim ${ }^{1,2}$ \& Asnarulkhadi Abu Samah ${ }^{1,3}$ \\ ${ }^{1}$ Department of Social and Developmental Science, Faculty of Human Ecology, \\ Universiti Putra Malaysia, ${ }^{2}$ Department of Moral, Civics and Character Building Studies, \\ Faculty of Human Sciences, Universiti Pendidikan Sultan Idris, ${ }^{3}$ Institute for Social Science \\ Studies, Universiti Putra Malaysia, 43400 Serdang, Selangor \\ Email: asnarul@upm.edu.my
}

\begin{abstract}
This article discusses the prediction of human capital by community participation in decision making, implementation and benefit received among beneficiaries of a community project initiated by the Yayasan Sejahtera (YS). In the process towards community development, community members can enhance their skills, knowledge, abilities, and experience from their participation in the project. The previous study shows that there was a positive impact and benefit of community participation with increasing human capital aspect in community development. Meanwhile, in this study, the human capital was measured in terms of gaining and increasing knowledge, skills, and abilities from participating in the community project. This study used a survey design. The data were collected using a questionnaire that was developed based on the previous studies. A simple random stratified sampling technique was used to approach a total of 305 respondents. They were the participants from the 13 projects in the three states, namely Kelantan, Sabah, and Sarawak. Using the Structure Equation Model (SEM) analysis, generally, this study found that community participation (implementation and benefit received) has a significant prediction (49.2\% of variance) with human capital. The human capital developed by the participants in the YS project gave a positive impact on their quality of life.
\end{abstract}

Keywords: Community Participation, Human Capital, Community Project, Community Development, Quality of Life

\section{Introduction}

Community development is considered as an effort that leads to change in the community life (Asnarulkhadi, 2012). According to Maimunah Ismail (2001) in discussing community development in Malaysia context, refers to community development as a process of improving the quality of life of community including increasing the opportunities of employment and increasing the capacity of resources and services. One of the goals of community development to develop community capacity by maximizing resources for their social and economic benefit (Rahim \& Asnarulkhadi, 2003).

In this regard, 
the internal process is to build, restore and maintain their confidence, capacity, physical structure, economy and social status (Diacon \& Guimaraes, 2003).

Haman (2006); Barney (2003), stated that one of the community development efforts is through participation in poverty projects. To overcome poverty problem and socio-economic issues in the community, various projects has been implemented by various agencies including the non-governmental bodies. In Malaysia, Yayasan Sejahtera (YS) is well-known for the community development project with the aim to improve the quality of life, family and community in impoverished living areas. The community project can be seen as a process to develop a community with dynamic participation and progressive manner towards holistic change in their own setting. Participation in various level of stages carried out within the project or program can improve the community abilities through enhancement of their knowledge, skills and experiences, and this can be seen as human capital. Typically for a complete cycle, the community development process begins with participation in the planning, implementation and evaluation of the program (Asnarulkhadi, 2003). The depth of participation by community in the development projects have an impact to the quality of their lives, in term of human capital as well. Community participation also have ability to shape the capacity of some local individuals to take control of their lives, to bring justice and to anticipate future problems (Hayes, 1981). In this paper, the main focus on participation from community project towards their form of human capital emphasized on improvement of their life's context.

\section{Human Capital in Community Development}

Human capital development contributes to the benefits of competition in most capitals (Lee \& Lee, 2018; Bowles \& Gintis, 2007). Asnarulkhadi (2005) refers to human power or community power as human capital. It can be developed and enhanced through their participation in development project activities. Such participation allows the community to learn and identify needs, plan, formulate strategies, make decisions and implement plans. Human capital is also formed consciously through training and education and unconsciously through experience (Ostrom, 1993). The importance of investing in and developing human capital as a vital factor of production has continued to gain credit over the years (Son, 2010; Rocha et al., 2017). Van der Veen (2003) asserts that individual training and education in a community that takes place informally is also an alternative in community development. While non -formal education refers to the process of social learning that takes place in the community through agents of change as a driver in developing the community (Zahid et. al, 2008). Social learning occurred throughout the roles of agents working with community members on community problems solutions where the community learns to govern themselves beginning with identifying problems until carrying out responsibilities to overcome them. This indicates the occurrence of education where the participation of the local community in the development process (Asnarulkhadi et.al, 2007). Individuals who are exposed to formal or informal learning processes provide the potential for self-quality improvement itself. Brigss et.al (2007) stressed that the use of human capital helps local communities use natural resources sustainably and it is one of the factors to the success of sustainable development in rural areas. He also added that human capital can increase community income as well as reduce dependence on the outside community because they have their own knowledge. Knowledge is influenced by current activities and experiences of local people (Briggs et.al, 2007; Dan et.al, 2010). 
Emphasis on the human capital aspect in community development covering various life contexts. In the context of community groups, the importance of human capital in a particular community group is a step towards achieving better life change. Haslinda et.al (2009) in Mansor and Noradilah (2005) stressed that human capital is a self-potential that can contribute to the community and maintain a positive relationship with community members. The participation of community members with self-potential can contribute to aspects of community life change through networking, cooperation, skills and expertise in the community, economic resources, beliefs, self-esteem, and so on (Azizan, 2013). Alway (1998) also argues that community participation was closely related to the belief that will gain the benefits of training, financial assistance, knowledge acquisition, and access to resources. Andreata (2000) further in his study found that group activities in the community are a channel of development that ability to help the community share information and experiences between them. Moreover, through participation as well, there is a cognitive process related when community equipped with aspects of knowledge and the ability to make perceptions, think, understand and use those skills to achieve better life goals (Mansor \& Noradilah, 2009).

Community development involves a participative process of identifying and redefining local capacity and assets, applying resources, skills, and talent, and improving community assets and function in line with community values (Eversole, 2015). Community development also share recognition of knowledge, skills and learning processes, social networks and support, having a diverse local economy, and community infrastructure, as being important to community vitality and sustainability throughout their participation in community project (Jim Cavaye \& Helen Ross, 2019). The current article will be focusing direct on human capital from participation in development process of community project, which based on the supported by scholars. Brown (2016) presents community development as having facets of capacity, process, and outcome - of undergoing, actively engaging with, and adapting to, change throughout their participation itself.

\section{Methodology}

This study used a quantitative approach with a cross-sectional survey design. This approach enables the researcher to explain the level of participation among beneficiaries of YS projects selected through the random sampling technique. This study employed a random sampling method to ensure a representative sample selected from different areas and types of projects. The samples were drawn from the three states where the economic community development projects were carried out by YS using the proportional sampling procedure. From this process, a total of 305 respondents were selected and involved in this study. 
Figure 1 below shows the sample sampling procedure in this study.

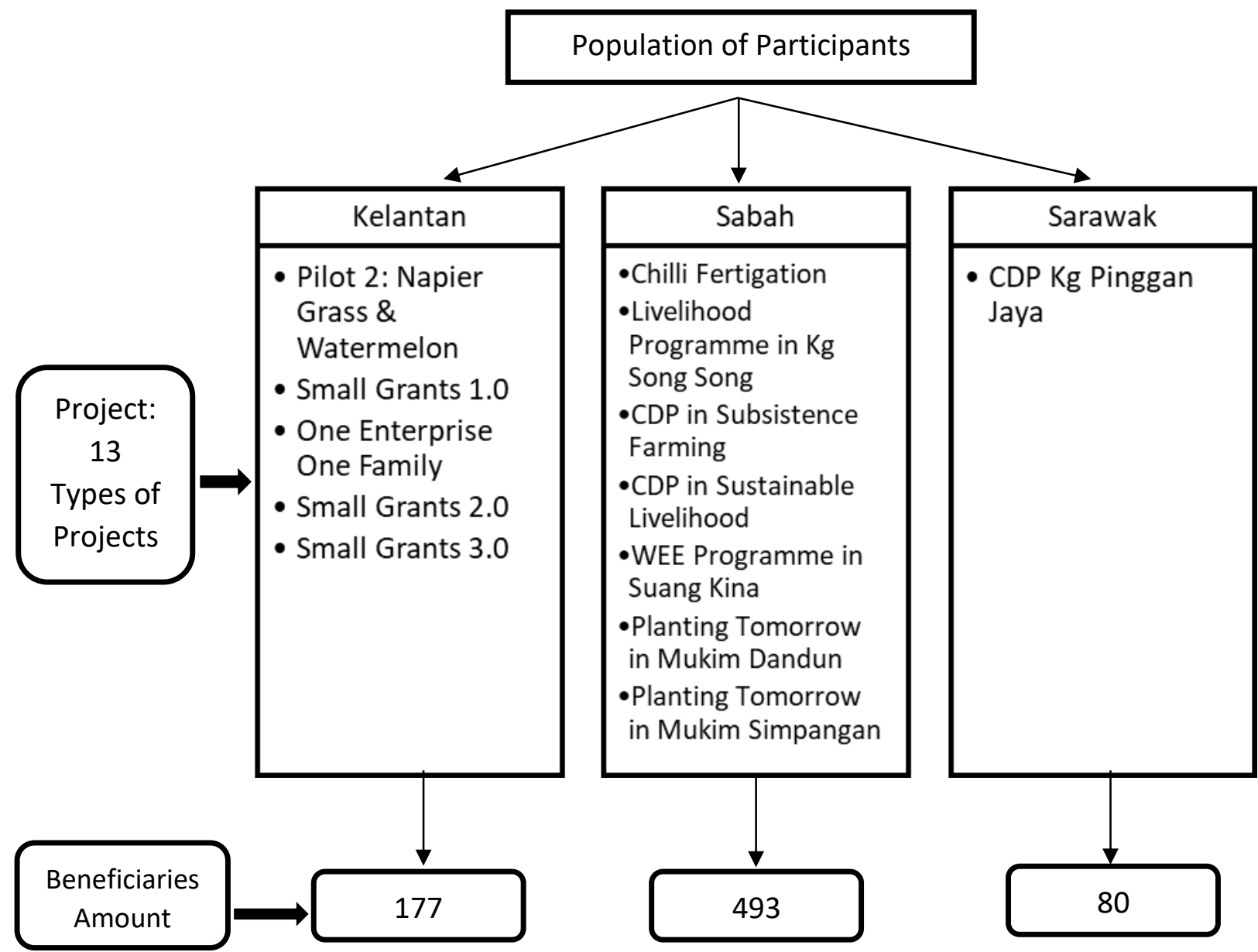

Figure 1: Procedure of Stratified Sampling

This research based on Cochran's (1977) formula to indicate the sample size and from that formula required 262 to represent 750 participants. To obtain a proportional random number of samples, the calculations required are as follows: -

$$
\left[\frac{\text { Participant Population }}{\text { Overall Population }}\right] \times \text { Sample Number Needed }
$$

The researcher made an increase in the number of samples by taking into account the adequate rate of return, unanswered questionnaires as well as other technical problems. An addition of $15 \%$ ( 43 respondents) of the sample size was made and made a total of 305 respondents. Once the actual number of samples is known, the process of identifying the respondents involved is done with the assistance of project assistants at each study location. Based on the calculation formula, the sample size for each project by state is as in Table 1: 
Table 1: Sample Size from The Population

\begin{tabular}{lcc}
\hline \multicolumn{1}{c}{ State } & Total of Participants & Sample of Participants \\
\hline Kelantan & 30 & 14 \\
Pilot 2: Napier Grass \& & 20 & 9 \\
Watermelon & 60 & 26 \\
Small Grants 1.0 & 55 & 24 \\
One Enterprise One Family & 12 & 24 \\
Small Grants 2.0 & & \\
Small Grants 3.0 & & 12 \\
Sabah & 26 & 20 \\
Chilli Fertigation & 50 & 47 \\
Livelihood Programme in Kg Song & & 13 \\
Song & 118 & 14 \\
CDP in Subsistence Farming & 44 & 41 \\
CDP in Sustainable Livelihood & 75 & 34 \\
WEE Programme in Suang Kina & 100 & \\
Planting Tomorrow in Mukim & & \\
Dandun & 80 & 305 \\
Planting Tomorrow in Mukim & & \\
Simpangan & & \\
Sarawak & 80 & \\
CDP Kg Pinggan Jaya & & \\
\hline Total & 750 & \\
\hline
\end{tabular}

This study using a set of questionnaires including measurement about participation and human capital. For participation, 28 items were formulated based on the instrument developed by Haris (1996) and Mohammed Bashir (2013b). Here, the participation refers to decicion making, implementation and benefit received by respondent. Meanwhile for human capital based on instrument developed by Thomas (2013), Garavan et.al (2001) and Fitzsimons (1999) consists of three elements known as knowledge, skill and abilitis.

In this study, Partial Least Squares - Structural Equation Modelling (PLS-SEM) was used to examine the relationship between three dimensional of participation (decision making, implementation and benefit received) towards human capital. PLS-SEM is a Systematic Procedure as described by Hair et. al $(2017 ; 2014)$ that, "PLS-SEM (also called PLS path modelling) is primarily used to develop theories in exploratory research. It does this by focusing on explaining the variance in the dependent variables when examining the model". PLS-SEM facilitates this study with meaningful diagrams and visuals as well as procedures that systematically test for each variable and items based on the research objectives and research hypothesis. The relationship between independent variables and dependent variables was tested by path analysis from the SmartPLS3.2.3 software. Clearly, the data were analysed using SmartPLS 3.2.3 software (Ringle et.al, 2005). 


\section{Finding and Discussion}

Based on the path diagram shows the relationship of predictor variable (exogenous) to the dependent variable (endogenous) for the study. The relationship of exogenous namely decision making, implementation and benefit received known as a predictor for endogenous which is human capital. There are 3 hypotheses tested in this structural model; to test the three dimensions of participation as mentioned as predictors with human capital. The results of this study were summarized in Table 2 as below: -

Table 2: Significance of Path in Model Structural

\begin{tabular}{|c|c|c|c|c|c|c|c|c|}
\hline Hyphothesis & Path Significance & $\begin{array}{l}\text { Std } \\
\text { Beta }\end{array}$ & $\begin{array}{c}\text { Std } \\
\text { Erro } \\
r\end{array}$ & $\begin{array}{c}t- \\
\text { value }\end{array}$ & Result & $\mathbf{R}^{2}$ & $\mathbf{f}^{2}$ & $\mathbf{Q}^{2}$ \\
\hline $\mathrm{H} 1$ & $\begin{array}{l}\text { Decision } \\
\text { making } \rightarrow \text { Human } \\
\text { Capital }\end{array}$ & 0.121 & $\begin{array}{c}0.07 \\
3\end{array}$ & 1.664 & $\begin{array}{l}\text { Hipotesis } \\
\text { accepted }\end{array}$ & $\begin{array}{l}0.4 \\
92\end{array}$ & $\begin{array}{c}0.01 \\
4\end{array}$ & $\begin{array}{c}0.31 \\
9\end{array}$ \\
\hline $\mathrm{H} 2$ & $\begin{array}{l}\text { Implementation } \\
\rightarrow \text { Human Capital }\end{array}$ & 0.179 & $\begin{array}{c}0.08 \\
2\end{array}$ & $\begin{array}{c}2.186 * \\
*\end{array}$ & $\begin{array}{l}\text { Hipotesis } \\
\text { rejected }\end{array}$ & & $\begin{array}{c}0.02 \\
3\end{array}$ & \\
\hline H3 & $\begin{array}{l}\text { Benefit } \\
\text { Received } \rightarrow \text { Huma } \\
\text { n Capital }\end{array}$ & 0.464 & $\begin{array}{c}0.08 \\
0\end{array}$ & $5.79 * *$ & $\begin{array}{l}\text { Hipotesis } \\
\text { rejected }\end{array}$ & & $\begin{array}{c}0.16 \\
5\end{array}$ & \\
\hline
\end{tabular}

Nota: ${ }^{*} p<0.01, * p<0.05$

Ho1 There is no significant correlation between participation in decision making with human capital.

Ho2 There is no significant correlation between participation in implementation with human capital.

Ho3 There is no significant correlation between participation in benefit received with human capital.

\section{Implementation and Benefit Received towards Human Capital}

The results shown for relationship between participation with human capital. The findings shown that participation in implementation and benefit received are significant predictors of human capital. Based on the results of the study, the researchers failed to accept the hypotheses for $\mathrm{HO} 2$ and $\mathrm{HO} 3$ by proving that respondents who are involved in implementing the project and get the benefits of the project contribute to the formation of their human capital. Rationally, through the participation in project, respondents earn meaningful learning process with sharing ideas and views exchange. This learning process was also a form of benefit that can be utilized by the community for a better life change. From the implementation and benefit received including formal and informal training as well contribute to human capital aspect in the community. This study supported by Asnarulkhadi (2005) who says that through the process of participation, community members can enhance their skills, knowledge, abilities, and experience. Midgley (1986) also explains that participation have ability to strengthen the capacity of individuals and communities to mobilize as well asself-help themselves. Community participation and human capital must be 
fundamental values that are integrated into community project at every stage - from decision making, through implementation and benefit received, to enabling community development to be meaningful and developed as part of a long-term strategy.

The standard coefficient value for implementation is $=0.179$ and the value of $p=0.035<.05$ while the benefit received shows the value of $=0.464$ and the value of $p=0.000<.05$. The findings of the analysis also show that the value of $R^{2}=0.492$ which is $49.2 \%$ of the variance that contributes to human capital from the implementation and benefit received of respondents in the project. The effect size $\left(\mathrm{f}^{2}\right)$ of human capital from the implementation recorded a small value of 0.023 while the benefit received $(0.165)$ recorded a moderate effect size $\left(f^{2}\right)$. From the results show that benefit received as more predictor for human capital over the implementation. It is based on the form of training and courses as well as the abilities obtained that can be benefited by the respondents from the participation in the project. For projects to be sustainable there must be community participation. This is because, according to Musa (2002), through participation, the community develop skills for collective action, maintenance and sustainability.

\section{Conclusion}

As conclusion, the participation in community development program enables the positive impact for the community itself and the organization as well. Community from YS project was gained benefit from their participation in term of human capital improvement that led to their life's improvement including knowledges, skills and abilities. From the human capital's aspects, the community will benefit it in term of life context especially in income and social skills. Hardina (2003) mentioned that the importance and benefits from participation to individuals, groups, organizations and communities have been widely discussed by scholars. Through participation, many benefits are gained by the community with material and nonmaterial aspects that can enhances their abilities and capabilities (Asnarulkhadi, 2005). Therefore, as recommendation from this study, community should be involved from the beginning of the activity planning until to the end of evaluation stage of participation, thus the community being able to understanding the issues arise in the community and being able to learn how to resolve them and it will lead to a sense of belonging within the community project. The community project that impacted to community will create the medium an independent among communities as effort to improve the better quality of life. The formation of human capital in the community enables produce community knowledgeable, experienced and capable community. Individuals participated in group activities can form internal empowerment such as strength in dealing with problems (Zimmerman \& Rappaport, 1998). Knowledge as a cognitive factor (Haris, 2006) and occur in the process of capacity formation of individuals, groups, or communities and can be shown through the ability and capability of community to understand, interpret problems and needs (psychological empowerment) (May, Mendelson \& Ferketich, 1995).

In other hand, in the process of community development, various aspects should be emphasized especially in expanding the form of programs and activities, training and skills. If communities are involved in project formulation, design and implementation, the projects are likely to be sustained, more cost effective there's more equitable distribution of project benefit, it also leads to better designed projects. According to Starkey (2002), participatory user focused network can have all stakeholders work together and encouraged to collaborate and learn from each other for better impact in community. In this case, community is a target 
group in the development that acts as a facilitator, executor, assessor, evaluator rather than a co-creator from the beginning of the program. If such aspects are emphasized in the implementation of a program or activity, it may allow for empowerment to occur within the community with the power form of abilities as human capital. Fundamentally, the process of community development should be involving the ability of the community to determine their goals and the desired pattern of change or progress in the context of their living environment as initial starting in the project (Asnarulkhadi, 2011). An active participation as process within the community project context will enable the form of human capital, that had supported from this study which is through the process of participation in term of implementation and benefit received, community members can enhance their skills, knowledge, abilities, and experience in their field of projects.

\section{References}

Alawy, A. S. (1998). Accessibility of women's groups to agricultural extension services in Kenya: an exploratory and descriptive study of factors, needs, and problems. The Ohio State University.

Andreata, S. (2000). Focusing on Change: Utilising Facilitated Farmer Groups as Learning Vehicle. Proceedings of the Australasia-Pacific Extension Network National Forum, Melbourne, Australia: The Australasia Pacific Extension Network (APEN).

Asnarulkhadi, A. S. (2005). Pendayaupayaan komuniti melalui penglibatan: Satu penilaian umum terhadap pembangunan komuniti di Malaysia. Malaysian Journal Social Policy \& Society, 2, 75-91.

Abu Samah, A., \& Aref, F. (2012). The theorical and conceptual framework and application of community empowerment and participation in process of community development in Malaysia. Journal of American Science, 7(2), 187-195.

Hamzah, A. H. (2009). Program Pembangunan Komuniti: Satu Strategi Untuk Pengurusan Berkesan, Prosiding Seminar Kebangsaan Pembangunan Komuniti, Kuala Lumpur, 14 Julai, 2009. Perpustakaan Negara Malaysia.

Bahari, A. (2013). Bekerja dengan Komuniti. Kangar: Penerbit Pustaka Qarya. ISBN 978-96711952-0-8.

Barney, I. (2003). Bussiness, Community Development and Sustainable Livelihood Approach. Community Development Journal, 38(3), 255-265.

Barr, A. (1995). Empowering communities-beyond fashionable rhetoric? Some reflections on Scottish experience. Community Development Journal, 30(2), 121-132.

Briggs, J., Sharp, J., Yacoub, H., Hamed, N., \& Roe, A. (2007). The nature of indigenous environmental knowledge production: evidence from Bedouin communities in Southern Egypt.Journal of International Development: The Journal of the Development Studies Association, 19(2), 239-251.

Brown, K. (2016). Resilience, development and global change. Abingdon: Routledge.

Cavaye, J., \& Ross, H. (2019). Community resilience and community development: What mutual opportunities arise from interactions between the two concepts?. Community Development, 50(2), 181-200.

Eversole, R. (2015). Knowledge partnering for community development. Abingdon: Routledge.

Fernando, J. L. (2003). NGOs and production of indigenous knowledge under the condition of postmodernity. The Annals of the American Academy of Political and Social Science, 590(1), 54-72. 
Fitzsimons, F. (1999). Human Capital Theory and Education. The Encyclopedia of Education. London: McMillan.

Hair Jr, J. F., Hult, G. T. M., Ringle, C. M., \& Sarstedt, M. (2021). A primer on partial least squares structural equation modeling (PLS-SEM). Sage Publications.

Hamann, R. (2006). Can business make decisive contributions to development? Towards a research agenda on corporate citizenship and beyond. Development Southern Africa, 23(2), 175-195.

Haris, A. W. (2006). Khidmat Sosial di Malaysia. Pembangunan Komuniti : Isu-Isu Genting Dalam Pelaksanaan Kemajuan. Kuala Lumpur: Penerbit Universiti Malaya.

Haslinda, A., Turiman, S., Abd. Halim, S., Sarjit, S. G., Nobaya, A., \& Dzulhailmi, D. (2009). Belia dan Pembangunan Modal Insan. Serdang: Penerbit UPM.

Hayes, S. E. (1981). Uses and Abuses of Community Development. A General Account. Community Development Journal, 16(3), 221-227.

Lee, Y., \& Lee, J. Y. (2018). A multilevel analysis of individual and organizational factors that influence the relationship between career development and job-performance improvement. European Journal of Training and Development, 42(5/6), 286-304.

Maimunah, I. (2001). Malaysian Women in Rural Development and Entrepreneurship: From Rural Producers to Urban Entrepreneur. Asean Academic Press, London.

Mansor, A. T., \& Noradilah, M. N. (2009). Kesejahteraan Psikologi dan Modal Insan dalam Kalangan Belia dalam Belia dan Pembangunan Modal Insan. Serdang: Penerbit UPM.

May, K. M., Mendelson, C., \& Ferketich, S. (1995). Community empowerment in rural health care. Public Health Nursing, 12(1), 25-30.

Musa, S. M. E. (2002). Feeder roads and food security in balancing the load: Women, gender and transport. UK: Zed Books Ltd, 79-94.

Parson, R. J. (1991). Empowerment: Purpose and practice principles in socialwork. Social work with groups, 14(2), 7-21.

Rocha, R., Ferraz, C., \& Soares, R. R. (2017). Human capital persistence and development. American Economic Journal: Applied Economics, 9(4), 105-136.

Starkey, P. (2002). Local Transport Solutions for Rural Development. UK: Russell Press.

Thomas, K. (2013). Relationships Between Organizational Capital and Employee Work Performance in Malaysian Public Organizations (Doctoral dissertation, Universiti Putra Malaysia).

Veen, R. V. D. (2003). Community development as citizen education. Int. of Lifelong Education, 22(6), 580-596.

Zahid, E., Asnarulkhadi, A. S., Mariani, M., Jamilah, O., Hanina, H. (2008). Pembangunan Modal Insan: Saluran Kemerdekaan Orang Asli Semenanjung Malaysia. Persidangan Perdana Pribumi Malaysia. Anjuran Universiti Darul Iman Malaysia pada 25\&26 Oktober 200, Dewan AI MuktafiBillah Kampus KUSZA, Gong Badak, Kuala Terengganu.

Zimmerman, M. A. (2000). Empowerment theory: Psychological, organizational and community level of analysis. Dalam J. Rappaport \& E. Seidman (Editor), Handbook of Community Psychology (hlm. 43-59). New York: Kluwer Academic/Plenum Publishers. 